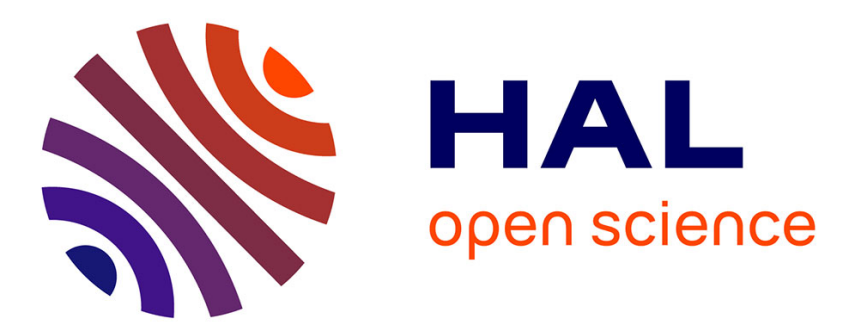

\title{
Biopolitics, the State, and Displacements of Children in France between the End of World War II and the Fall of the Empire, 1945-1970 \\ Yves Denéchère
}

\section{- To cite this version:}

Yves Denéchère. Biopolitics, the State, and Displacements of Children in France between the End of World War II and the Fall of the Empire, 1945-1970. Child Migrations and Biopolitics. Old and new Expériences in Europe, 2020. hal-02925925

\section{HAL Id: hal-02925925 \\ https://hal.science/hal-02925925}

Submitted on 31 Aug 2020

HAL is a multi-disciplinary open access archive for the deposit and dissemination of scientific research documents, whether they are published or not. The documents may come from teaching and research institutions in France or abroad, or from public or private research centers.
L'archive ouverte pluridisciplinaire HAL, est destinée au dépôt et à la diffusion de documents scientifiques de niveau recherche, publiés ou non, émanant des établissements d'enseignement et de recherche français ou étrangers, des laboratoires publics ou privés. 


\section{Biopolitics, the State, and Displacements of Children in France between the end of World War II and the Fall of Empire (1945-1970)}

Yves Denéchère

\section{Introduction}

The end of the Second World War and the fall of the French colonial empire generated favourable circumstances for biopolitical practices regarding what were considered to be high-stakes groups, i.e. people of mixed race, women/mothers and especially children. Childhood had become essential for peace and the postcolonial era. Indeed, as promises for the future, childhood and youth were subject to conservative or prospective biopolitics. This often entailed the uprooting of children and teenagers from former occupied or colonized territories. Though memories of these displacements are still alive among those who experienced them, their history is still to be written. Based on three case-studies, the French occupation of defeated Germany (1945-1949) and the wars of decolonisation and independence in Indochina (1946-1954) and Algeria (1954-1962), this contribution will focus on the biopolitical practices regarding childhood in the context of the end of war and empire.

A concept put forward by Michel Foucault (1926-1984), "attentive to the specific mechanisms that frame the lives of individuals and populations," biopolitics - or power over life and human beings (Marzocca, 2009; Genel, 2004) - are essentially practised by the state, but also by other actors linked to it. Youth, a "very important social fact" according to Pierre Bourdieu (1930-2002), - even if he considered that "youth is only a word" (Bourdieu, 1978) played an important role in the construction of Nazi Germany and colonial empires, and it remained a fundamental issue in the contexts of denazification and end of empires (Zahra, 2011; Boucher, 2014; Pomfret, 2016). For the French political authorities as for the actors involved on the ground (soldiers, social services, colonists, missionaries, humanitarian workers, promoters of new societies meant to push back decolonisation), "saving the children" became a pressing moral necessity.

Thus, in occupied Germany, French officers retrieved hundreds of children born to fathers who had been soldiers in the Occupation and German mothers (Denéchère, 2010); from the late 1940s until the 1970s, the Fédération des ouvres de l'enfance française d'Indochine (FOEFI, Federation of French Children's Charities in Indochina) "repatriated" thousands of Eurasian children to France (Denéchère, 2011); during the war in Algeria, from 1957 onward, the Association pour la formation de la jeunesse (AFJ, Association for Youth Education) took charge of hundreds of Yaouleds (i.e. street children, from the Arabic ya [come] and ouled [child, small]) in Algiers, and then sent dozens back to mainland France 
(Denéchère, 2017). In these three forced migrations, the biopolitical dimension is visible through both the ideologies at work and the processes of compelled integration/assimilation they entailed. Babies, children, and teenagers were uprooted and often became the subjects of policies desired or supported by the French authorities and carried out by various organisations. Mothers were separated from their children, fathers were ignorant of their children's fate as well as that of their mothers, and siblings were separated. These displacements were linked to a complex system of questions in political and diplomatic, economic and social, demographic and human, philosophical and religious terms (RHEI, 2012). Against the backdrop of populationism (Rosenthal, 2003) and post-colonialism (Mbembe, 2006; Schaub, 2008), the issues of children and youth produced policies that raised questions about the place of the child as a subject in French society during the thirty prosperous years after the Second World War.

In order to grasp these complex realities, this chapter draws on a great variety of sources. Public archives - particularly the French National Archives and the Archives of the Ministry of Foreign Affairs - and those of private organisations - especially FOEFI and AFJ - helped identify the main actors and comprehend their role in the retrieval of these children. An approach through representations was possible thanks to media: written press, audiovisual production, Internet forums and sites of associations. Private archives and the first-hand accounts of organisation leaders made it possible to better grasp the motivations of those involved. Finally, the accounts and testimonies - more or less critical - of the people directly concerned by this story are irreplaceable. Indeed, when writing the history of these displacements researchers need to take into account and consideration the experiences and trauma they generated. This approach inevitably leads to interactions between the historian and the actors/witnesses themselves. Individual and collective interviews, participant observation (Soulé, 2007), and numerous discussions about the work of a historian, enabled me to write a humanist history respecting personal stories. In this research, it is very important to understand the interracial or intergroup relationships, the future of the children, and the representations which they bore (Stoler, 2002). Constructing this history, writing it, and then presenting it to the Eurasians and formers yaouleds - to reciprocate for the confidence demonstrated during our meetings - was a fascinating research adventure. It was also a perilous and delicate task, as it crossed conflicts of memory linked to the French colonial presence in Indochina and Algeria, and its postcolonial prolongations, as well as conflicts of intimate memories with wounds quick to reopen.

The first part presents the three child migrations in their respective contexts. In doing this, it will look at the "humanitarian" dimension of child rescues. The second part is a 
syncretic analysis of different biopolitical issues surrounding these displacements. It will also question, on the one hand, the role of the state and other actors involved and, on the other, the postcolonial dimensions of these migrations.

\section{I - Displacing children in order to save them: a humanitarian action?}

Children born under French occupation in Germany, Eurasian mixed-race children in Indochina, and the yaouleds in Algiers were taken into care for humanitarian reasons. This decision was taken not only for social but also for political reasons, as the French authorities were aware of the demographic potential and the interest of controlling these children.

1 - Retrieving children with French blood from the French Zone of Occupation in Germany $(F Z O)$

Despite the fact that Allied soldiers were forbidden to fraternise with the local people, relationships inevitably formed between French men and German women in the French Zone of Occupation. Thus between fifteen and twenty thousand children were born, whose fate was sealed by humanitarian, political, and social considerations. A similar case was that of the children born in France to a German father and French mother during the occupation between 1940 and 1944 (Virgili, 2009; Hudeman, 2005).

In the post-war context, immigration was becoming inevitable in ensuring France's recovery and repopulation. The Haut Comité consultatif de la Population et de la Famille (HCPF, High Consultative Committee on Population and the Family) created in April 1945 therefore recommended to tap into the flow of refugees coming from Germany. On 18 May 1945 General de Gaulle, President of the Provisional Government, asked the HCPF to look into bringing back to France children of all nationalities who were "currently orphans or isolated in Germany." In April 1946, Pierre Pflimlin, Under Secretary of State in charge of Population, specified that "it was no longer a question only of children with French bloods in their veins." (Rosental, 2003). In June of 1946, during a meeting at Institut national d'études démographiques (INED, National Institute of Demographic Studies), the renowned professor of medicine and paediatrician Robert Debré and the demographer Alfred Sauvy supported the implementation. ${ }^{1}$

The German towns in the FZO communicated the list of children born to German mothers and fathers presumed either to be French or from the Allies to the French officers in charge of Personnes Déplacées et Réfugiées (PDR, Displaced Persons and Refugees). The 
first question which arose was whether paternity had been recognized by the French soldiers. The cases were quite diverse: i.e. some soldiers knew about the pregnancies and others did not, some left without leaving an address while others refused to recognize the child... ${ }^{2}$ The other important question was whether a mother would decide to abandon her child when the father showed no interest in caring for him. However, given the disastrous economic situation in which Germany found itself after the war, it was materially very difficult to raise a child. Moreover, the entourage and society as a whole exerted great pressure on the mothers to give up their children. This social pressure reinforced that which wasexerted by the French authorities.

When giving up her child, a German woman had to sign an "Official statement of the abandonment of a child to the French authorities". There, the mother swore on her honour that she "had a child... with a French father" and wished "for personal reasons to abandon it to the French authorities." The latter then had two months to "verify the child's filiation and prepare his reclassification in his paternal family as much as possible." However, information on the father's identity was often scanty. On the other hand, the mother had two months to change her mind before her decision became definitive. The statement specified that if the investigation did not succeed in determining the child's French filiation, it could be returned to its mother or left with the German authorities for want of a better solution. The consequences of abandonment were explicit: renouncing all rights if the child was entrusted to its father's family and "acceptance of adoption." ${ }^{3}$ Children were then admitted into care homes in the FZO and actions could be initiated in order to ensure their adoptions in France. French candidates for adoption had to fill in a file. A social worker and the care home supervisors decided which child best corresponded to the criteria defined by the applicants. Apart from spontaneous, individual applications, charitable works associations like Les Nids de Paris (The Nests of Paris), L'Amitié chrétienne (The Christian friendship) or La Fondation d'Heucqueville (Heucqueville Foundation) acted as intermediaries. Their role was to find adoptive parents and manage the children's transfer to France. These charities did not accept to put mixed-race children, who had been born to Arab or black soldiers, up for adoption, because they believed that adoption applicants were not ready for this type of child. ${ }^{4}$

How many children of a French father and a German mother were adopted by French families? A 1952 list counts 384 names. Another source, from 1950, indicates that 961 children were repatriated, "of whom 286 were returned to their own [father's] families and 452 put up for adoption." ${ }^{5}$ Either way, several hundred German mothers, several hundred French fathers, several hundred adoptive French families, and of course several hundred adopted children, therefore thousands of people, were the active or passive actors of this story. 


\section{2 - Taking mixed-race children of Indochina into consideration}

Like in the FZO, the French military presence in Indochina generated relationships, whether romantic or forced, brief or lasting, from which were born Eurasian children of mixed race, subjects of the French governments race policy, well studied since (Rolland, 2006). If the French father was married to an Indochinese woman and recognised the child, it became French; if the father was already married - and therefore could not recognise the child - or if he lost interest, the child took the mother's nationality. A 1928 decree opened another path in declaring that "any individual, born in Indochina to parents of whom one, remaining legally unknown, is presumed to be of the French race, shall be able to obtain ... recognition of French status." (Saada, 2007; Rosen Jacobson, 2016). In order to be considered of "French race", mixed-race children in Indochina - Eurasian or Africasian because there were also black soldiers in Indochina - had to not only "have French blood in their veins", but also be socialised in a milieu of "French culture" (Saada, 2007). The application of the 1928 decree therefore also supposed that these children would not only be identified but also educated particularly in religious institutions - with their mothers' agreement.

In 1945, William Bazé (1899-1984), a Eurasian born in Annam, a rubber-tree planter, Gaullist and resistance fighter, was concerned about the fate of mixed-race people and created a foundation which became the Fédération des æuvres de l'enfance française d'Indochine (FOEFI) in 1949 and was registered as a state-approved charitable works organisation in 1950. Unable to have children themselves, the Bazés took in and raised fourteen Eurasian orphans. $^{6}$ During the war in Indochina, the presence of a large expeditionary force considerably increased the number of mixed-race children and compounded the question of where they fit into Indochinese society which tolerated French domination less and less. Starting in 1947, the foundation began to evacuate Eurasian children to France with the help of the French Minister for Overseas Territories. Grants and donations made it possible for the FOEFI to buy property, particularly in the Touraine region to care for boys, and in the Ain region for girls. ${ }^{7}$

After the Geneva Accords in July 1954, which sanctioned the division of Vietnam into two independent states, FOEFI continued to "repatriate" - that was the term used - mixedrace children in order to make them "French in soul and attributes". Indeed, an agreement between the French and Vietnamese governments allowed the Eurasians and Africasians who had been cared for by a French charitable work organisations to settle in France "on account of the upbringing they had begun to receive." Mothers had to sign a "certificate of release" 
indicating that the foundation had the right, "with no further agreement on my part, to send my child to France or any country in the French Union, to study or acquire professional training there." Very often, the signatories did not understand very well what this decision entailed; their consent therefore posed significant problems (Firpo, 2016). Afterwards, the mothers had to, progressively, "take distance" from their children who stayed in care homes for a few weeks before their grand departure - by ship or airplane - which was most often of great dramatic intensity. ${ }^{8}$ The FOEFI, a simple organisation, found itself invested with a biopower delegated by the government, which it wielded with complete authority and with the financial support of the State. It sent more than five thousand mixed-race children to France.

The Fédération saw it as its mission to bring up all its "repatriated" Eurasian wards together, in order to ease the brutal shock of their changed lives thanks to a collective, even generational, acculturation. Problems arose when the group homes' neighbours refused to accept the presence of these children, and the FOEFI was forced to scatter small groups of children in many different homes. ${ }^{9}$ They were brought up and educated in order to integrate French society in the best possible way. Here is how one former ward summed up her experiences: "It was thanks to the 'Fédé' that I could study, become a fully-fledged French citizen, and be useful to my country, France. ${ }^{10}$ Other former residents however refuse to express the least bit of gratitude towards an institution that decided for them a fate they had not chosen. ${ }^{11}$

\section{3 - Protecting yaouleds from the violence of the Algerian War}

From the beginning of the Algerian war (1954), but especially from 1958, for the disciples of French Algeria, the future came with apprehension over relationships between French citizens and colonial peoples. The "Muslim children of Algeria" were considered to be a major issue which needed to be dealt with as a priority in order to open a new colonial chapter, whatever the variations of that may be.

While running "The Battle of Algiers" (January-September 1957), General Massu (1908-2002) remained convinced that it was necessary to take care of the children, especially the boys "who roam in swarms in the streets of $\mathrm{Bab} \mathrm{El}$ Oued and elsewhere, in order to protect them as much as possible from explosions and other blows." ${ }^{12}$ His wife Suzanne (1907-1977), would implement this idea. She had joined la France Libre in 1940 then was commander of the Rochambeau Group that accompanied Leclerc's Forces françaises libres (FFL, Free French Forces) in 1944; she commanded the female division of the French Expeditionary Corps in Indochina. ${ }^{13}$ She married Jacques Massu in 1948 and followed him to 
Algeria. In 1957, "powerfully supported by my husband" as she stated, Suzanne Massu founded the Association pour la Formation de la Jeunesse (AFJ) whose goal was "the aid, protection, safeguard, and professional and moral education of youth"14, with pedagogy inspired by Hebertism, Scouting, social Catholicism and military discipline. Like the Bazés, the Massus also lived out their commitment in personal terms by caring for and adopting two Algerian children, Malika and Rodolphe. ${ }^{15}$

The organisation opened a Youth Centre in Algiers whose goal was to care for the children in distress who lived from begging, pickpocketing, or odd jobs (i.e. shoeshine boys or porters) and slept on the streets of the Casbah (popular Muslim neighbourhood) or in the Moorish baths. ${ }^{16}$ Between six and seven thousand such children were estimated to be living in Algiers. Those picked up by the AFJ came from many varied backgrounds: some were orphans while others had run away from their families or had been abandoned. They hailed from the bled, Kabylie, or the Casbah. Their lives had been devastated by the war, which had increased poverty, the destruction of traditional societies, and rural exodus (Taraud, 2008).

After the episode of 13 May 1958 which brought General de Gaulle back to power and maintained the hope of a new Algeria, the Massus became strongly committed to a social project founded on the younger generations. But from 1960 on, any idea of a new French Algeria was definitively obsolete. The AFJ found itself between a rock and a hard place: on one side the OAS (Organisation armée secrète) who - by using violence - wanted to maintain French Algeria at any price and the FLN (Front de libération nationale) on the other, who won the country's independence on political grounds.

In September 1961, a serious decision was taken: after a summer camp in Béarn (in the southwest region of France - Pyrénées-Atlantiques), the youngest thirty-five children would stay in France, "in the illusion of a prolonged holiday rather than exile." ${ }^{17}$ After the Evian Accords in March 1962, which ended the Algerian War, the AFJ organised the transfer of other children to Béarn, with the signed agreement of their parents. Out of 177 children, "66 were repatriated, 110 returned to their families, and one killed by the OAS." 18 Moussa A.C., one of the teenagers (sixteen years old at the time), reported that they left Algiers without advance notice, without explanation, without being able to bring all their belongings, without saying goodbye to their families, and wondering if the latter had even been informed. Daniel Belafekir, fourteen at the time, was also part of the group. He wrote: "The day we left, to reach the port discretely, we had to cross the city in military vehicles covered in tarps so as not to raise anyone's curiosity in Algiers. This manoeuvre obviously resembled a kidnapping more than children going on a holiday." 19 
For Jacques Massu, these adoptions were "proof that integration, for which [he] had always fought, was possible and not a pipe dream", as he stated in $2000 .{ }^{20}$ These declarations show that there was indeed a political dimension to the Massu's social and humanist work, aimed at integrating the two communities in a new French Algeria. The AFJ's action was consistent with the psychological war waged by the French Army, aiming to counter FLN's propaganda on the effects of the French domination, and to prevent the yaouleds from joining the armed struggle (Denéchère, 2017).

In the three cases quickly mentioned here, indisputably humanist and humanitarian motives led to decisions and actions being undertaken to "save the children". They also bring forward two fundamental questions, of risks and of purpose and means. What would have become of these children had they not been displaced? What did they risk? How was this risk measured and by whom? For the French authorities, the children of the FZO, the Eurasian children, and the yaouleds were doomed to a gruesome fate in a ruined Germany, a communist Vietnam, and an independent Algeria. It was then a matter of saving them, by any means possible, given the urgency of the situation. Some children had no identity papers, some were confused with others and a few still had family in the area. That was of little importance because to displace them was to save them. Today, those concerned by these measures have diverse understandings of the risk incurred. Most of them have accepted the notion and the idea that the ends justified the means, others insist more on the price they had to pay, especially by abandoning their original cultural identities. Children were, in fact, the objects of transnational relations and saw their lives as well as those of their families completely turned upside down by uprooting and migration. It was often unclear whether these forced displacements resulted from humanitarianism, military action, or politics. This ambiguity should be examined further.

\section{II - Ideologies and biopolitics at work in the displacement of children}

The one-way ticket to assimilation into French society brings up numerous questions regarding the instrumentalization of children in post-war and postcolonial contexts. In the three cases presented here, the decisions and the social care of the children originated with strong personalities (such as Bazé, Debré, Sauvy, or Massu, among others) committed to the Resistance and the Second World War, with the strong political convictions that a new society was possible, in post-war France, as in Indochina or Algeria. The French government had 
more or less taken charge of the displacement of children, but it mainly delegated a biopower (power over life) over these children's lives to the organisations and their directors.

\section{1 - Populationism at work in the post-war years}

In the singular context of the Allied occupation of Germany, the conditions under which children of French blood were picked up need more clarification. In the name of which philosophy, which policy, did the Provisional Government and the first cabinets of the Fourth Republic authorise and regulate these very particular adoptions? If the exceptional procedure which was followed, as well as the desire to erase all traces in the name of the higher interest of France, are not the symbols of a state affair, couldn't these displacements be considered state adoptions at the very least?

In order to have the children born in the FZO adopted in France, it was first of all necessary to find them and verify their abandonment because, according to the July 1939 legislation (family law), for a child to be adopted in France, it first had to be abandoned. After the abandonment by their mothers, the children were examined by a French doctor. If their state of health was satisfactory, they were admitted into French childcare homes, first created as early as $1945 .{ }^{21}$ Care of children in these institutions seems to have been serious and professional. Most who arrived in poor health recovered normal development, which leads us to believe that they were well cared for and fed.

The crucial factor determining whether the French authorities took charge of an abandoned child was its French lineage. But it clearly seems that another factor was taken into consideration, and perhaps even more so. In the prescribed period of two months, it was not only a matter of verifying the children's health and potentially caring for them but also of choosing them. A "medical commission composed of childhood specialists and psychotechnicians" regularly drew up lists of children authorised to be transferred to France. ${ }^{22}$ All of this was in compliance "with the instructions given by the Population Ministry who refuse[d] to admit idiot or abnormal children into France." 23

According to a 1952 report, "only children whose incurable physical or mental deficiency would have made adoption impossible were not sent to France because this procedure's only goal was to allow the children to find families." While mixed-race children having no chance of being adopted in France were sent to the African colonies, some children were "returned to the German authorities, especially in cases where their abnormal state rendered impossible all hopes for adoption." ${ }^{24}$ Although the absence of proof of French origin was highlighted, the archives confirm that refusal to transfer children to France was 
essentially linked to the state of their health. The children's intelligence quotients and development being low, PDR directors even considered that "German mothers preferred to abandon abnormal children to the French services." Unpleasant consequences resulted from this observation: "The massive return [of children] to German mothers...will not happen without stirring up emotion and spreading the idea that the French government is racist like in the best years of the Nazi regime." 25

Indeed, the policy of abandonment/adoption practised by France in the FZO was inspired by political and biopolitical considerations linked to the post-war context. The absence of a German government allowed for extraordinary procedures. The systematic verification of the abandonments of children of French origin did not occur without pressure being put on fragile mothers who found themselves in a very difficult economic and social situation. From the spring of 1949 onward, French authorities' desire to reverse the movement was due to the decrease in the number of children concerned, but especially to the restoration of a government in West Germany and the necessity to integrate it into the European Community under construction. The operation being "more and more delicate every day", French authorities in Germany proposed its "cancellation, pure and simple."26

The repatriations and placements of children could be considered state adoptions because French interests were constantly being put forward to justify one decision or another or the need for policy evolution. The French government also tried preventing all future claims. It was deemed necessary to erase the traces of these unilateral procedures by retrieving the documents from the relevant German administrations. For this reason, the adoption files were sealed, making it so that the majority of those who were most directly concerned by these events, the adoptees themselves, never knew they were adopted. No adoptive family in 1948 would have boasted about having adopted a German child. In this way, Mr Prugnaud was over sixty years old when he found out the truth after his adoptive mother had died. Today, the organisation Cours sans frontières (Hearts without Borders) works for the recognition of these war children. ${ }^{27}$

Although state interests were the driving force behind the abandonment/adoption policy, it is important to question if those excluded the children's interests. Upon initial analysis, it does not seem to have been the case. However, no alternative which would have kept the children in their environment was put forward. It is true that the subsidiary dimension of international adoption practices appeared only later.

\section{2 - Two postcolonial prolongations}


The Eurasian children and yaouleds sent to France belonged to the last generation born in a colonial context and there was also a populationist dimension to their displacements. The FOEFI and the AFJ aimed to prove that, in spite of discrimination against Eurasians or the destitute backgrounds of the yaouleds, this generation could embody a colonial future that the independence of Vietnam in 1954 and Algeria in 1962 had abolished. Regardless of their background, these children found themselves in the same crucible which wanted to educate them, give them a future, make them French citizens... but also deprive the enemy of its future generation. The fact remains that there could still be "unbreakable links between two races and two civilisations", ${ }^{28}$ all the while being perfectly integrated into French society. These children felt as if, upon their arrival, everyone wanted them to assimilate very quickly into French society, ${ }^{29}$ "even to Frenchify [them]... which passed through forgetting what [they] had been before... It's too bad, it was political," emphasised one of them. For the managers, it was simply a matter of favouring "integration in mainland France". 30

As soon as Eurasian children and Yaouleds arrived in France, everything was done to show them they had to make a fresh start. Their integration into French society required erasing origins and identity. Some personal belongings were confiscated and it was forbidden to speak Vietnamese, Berber, or Arabic at the risk of punishment. They had to forget the Buddhist, Hindu, or Muslim teachings they had received. The Eurasian girls, living with nuns, were all baptised and taught catechism. Eurasian and yaouled boys were invited to embrace Catholicism. Siblings were separated: Eurasian girls on one side, boys on the other; brothers stayed on the other side of the Mediterranean. Links with family at home remained very limited, i.e. a few letters, closely monitored.

The gendered nature of these singular transnational migrations is very clear. The FOEFI entrusted the education of the girls to a large number of religious establishments among which they were scattered. Still, over five hundred of them were communally raised and educated in the "abbey" home located in Saint-Rambert-en-Bugey, in Ain. Even if, theoretically, "the girls benefit[ted] from the same benevolent arrangements as the boys, because gone [were] the days when a woman [could] approach life without the means to hold a position allowing her to provide for herself "31 their "stories" and their journeys were quite different to those of the boys. In fact, the latter were hosted in secular institutions directly administered by the FOEFI (e.g. in Vouvray, Rilly, or Semblençay), with domestic staff, whilst the girls did all the housekeeping themselves, under the nuns' guidance. ${ }^{32}$ To later become good wives, mothers, and housekeepers, the girls were orientated towards secretarial work, sewing, or childcare... while awaiting marriage. The boys were more pushed to complete an education, as opposed to the AFJ teenagers - only boys - who were almost all 
orientated towards apprenticeships: e.g. plumbing and heating, baking, mechanics, horticulture. The leaders of the organisation considered France's abandonment of the harkis (Algerians who had fought for French Algeria) to be "a dereliction of duty, a scandal, a crime"; harki children were taken into care when school began in 1962. They too were only boys. $^{33}$

In the relatively closed centres of the FOEFI and the AFJ, the residents did not suffer much from racism, but outside Eurasians were called "slant-eyes", "chinks", or "green Chinese". Before letting the boys go to the cinema on a Sunday, the AFJ director would always repeat the same instructions: "Be polite, don't speak Arabic to each other, no fighting." ${ }^{34}$ As opposed to FOEFI wards who had arrived in France after undergoing naturalisation in Indochina and the attribution of French names, the yaouleds had to make a decisive choice: take Algerian nationality, or continue living in France after obtaining French nationality. Changing one's name was presented as a necessity by the AFJ. Abdelhamid accepted Daniel on his identity card but refused to change his name. ${ }^{35}$ At twenty-three years old, Ahmed changed his name and became Francis, to "blend" into the crowd. Mokrane became Michel, Mohamed, who found his name a bit discriminatory, became Marcel, even if everyone had called him Frédéric for a long time... On the other hand, Moussa refused any change, "by instinct, because it was the name given by dad and mum, a reminder of them." 36

For the FOEFI, the success of its mission to educate its wards was measured according to several criteria: a trade that assured employment, marriage to a French person, and psychological stability. University graduates, those who had "married well" and who were grateful to FOEFI approached perfection. For Suzanne Massu, AFJ's mission did not stop when the young people left the centres. She was "proud to say that it is extraordinary to observe how successful these boys are in military life, and how appreciated they are by their superiors. ${ }^{37}$ Here is, according to her, the perfect example of a success story:

"It was with profound joy that we attended the wedding of the young P. and Miss G. Before the ceremony, the evening before at the church in Jurançon, P. had chosen Catholicism. My godson, seeing as I must call him that as our Holy Mother Chuch would want, of course left the Centre to take a small apartment not far from that of his parents-in-law, who are affable and hospitable. In their home, they are impatient now to soon be expecting a happy event. It was a lovely success for our association, total and complete on the human level." ${ }^{38}$

The children of the FOEFI and the AFJ had comparable experiences of integration/assimilation in the postcolonial context. They had to abandon their native 
languages, discover a new culture as well as recognise themselves in it, constantly prove their ability to integrate at school or in military service. All of this was aimed at helping them become French like everyone else, to become fully-fledged citizens, endowed with all the rights French citizens have, but forged by coercive practices. This acculturation (such as denial of native culture and language, name changes, and compliance with another religion) is close to that implemented in Australia, Canada, the United States, or New Zealand in boarding schools reserved for indigenous children (Guay \& Grammond, 2016).

\section{Conclusion}

Beyond individual commitments, the different protagonists of French biopolitics in the FZO followed their own paths. French services in Germany acted pragmatically and were not unaware of the children's interests, while the Quai d'Orsay (Foreign Affairs Ministry) and the High-commissioner in Germany took information into account that was mainly political and diplomatic, and the Public Health and Population Minister leaned more on ideological and populationist thinking.

The one-way ticket to assimilation organised by the FOEFI and AFJ brings up the numerous questions posed by instrumentalising children in the postcolonial context (Saada, 2007). Over and above international power plays and the military and ideological defeats of decolonisation, children were a major issue for traumatised societies. The state assigned them a role of catharsis, as was for example the case of the American "Operation Babylift" launched at the end of the Vietnam War, in 1975 (Sachs, 2010; Denéchère, 2013).

Without erasing the differences between the two groups of children from Indochina and Algeria, nor the specific contexts and actors, both Eurasians and yaouleds were subject to well thought-out programmes aimed at turning some into vectors of the former colony and presenting others as living proof that another path was possible in Algeria. The inevitability of decolonisation rendered these objectives pointless. Although the failure of postcolonial undertakings orchestrated by the two organisations is obvious, in that they did not bring about the new, hoped-for colonial episode, it contrasted with a certain success in the education given to these children and young people. Although it is impossible to put forward precise numbers, most of them became "French citizens like everyone else" as they liked to define themselves. Their prices to pay were uprooting and the abandonment of their native cultural identity, without actually escaping from a certain racialisation, even if republican universalism was emphasised.

Above and beyond the question of the legitimacy of these organisations to wield a delegated biopower also lies the question of the responsibility of the French government. 
Starting in the 1960s, it progressively distanced itself from these organisations and their actions, particularly by reducing their funding. The international context was evolving: it was time to turn the page on colonialism and embrace the transnational movement for children's rights enacted in the 1959 UN Declaration. Still, state services implemented another displacement of children based on populationist ideology: more than two thousand state wards from Reunion Island were sent to rural France in order to repopulate it from the 1960s to the 1980s (Jablonka, 2007). ${ }^{39}$

The FOEFI mission ended in 1976, and the organisation was dissolved in 1983. Suzanne Massu's death in 1977 marked a turning point for the AFJ. In hindsight, most FOEFI and AFJ children, the oldest of whom are over eighty, have a rather serene perspective over their childhoods and the treatment to which they were subjected. The foefiens and foefiennes, as they call themselves when they meet at the organisation they created, ${ }^{40}$ share the same analysis: "if the lucidity we have acquired pushes us to recognise how lucky we were to have stayed alive thanks to FOEFI, it also leads us to say, without being ungrateful, that everything was not perfect in the best of all possible worlds." ${ }^{41}$ Michel F. summed up the general feeling among former AFJ youth: "I don't know what would have happened to us if we had not been in those centres." Certain Eurasian women believe that, if they had stayed in their country, they would have become "whores for the Americans". 22 At the same time, everyone demands the right to know, to understand why and how they were victims of biopolitics that forever turned their lives upside down.

\author{
Yves Denéchère, \\ Professor of Contemporary History, \\ Université d'Angers, TEMOS CNRS \\ EnJeu[x] Enfance et Jeunesse Programme
}

References:

- Boucher E. (2014), Empire's Children: Child Emigration, Welfare and the Decline of the British World, 1867-1967 (Cambridge: Cambridge University Press)

- Bourdieu P. (1978), «La jeunesse n'est qu'un mot», interview of by Anne-Marie Métailié, in Les jeunes et le premier emploi (Paris: Association des Ages) 520-530.

- Denéchère Y. (2010), «Des adoptions d'État: les enfants de l'occupation française en Allemagne, 1945-1952 », Revue d'Histoire Moderne et Contemporaine, n57-2 (April-June 2010): 159-179.

- Denéchère Y. (2012), "Les "rapatriements" en France des enfants eurasiens de l'exIndochine. Pratiques, débats, mémoires », Revue d'Histoire de l'Enfance Irrégulière, n¹4: 123-139.

- Denéchère Y. (2013), « Babylift (avril 1975) : une opération militaro-humanitaire américaine pour finir la guerre du Viêtnam », Guerres mondiales et conflits contemporains, $\mathrm{n}^{\circ}$ 252, (Paris: Presses Universitaires de France): 131-143. 
- Denéchère Y. (2017), "Les "enfants de Madame Massu". Euvre sociale, politique et citoyenneté pendant et après la guerre d'Algérie (1957-1980)", Revue d'Histoire Moderne et Contemporaine, $\mathrm{n}^{\circ}$ 64-3 (July-September 2017): 125-150.

- Firpo C. E. (2016), The Uprooted: Race, Children, and Imperialism in French Indochina, 1890-1980, (Honolulu: University of Hawai'i Press) with: "Maternal consent in the postcolonial era", 138-142.

- Genel K. (2004), « Le biopouvoir chez Foucault et Agamben », Methodos (April 2004).

- Guay C. \& Grammond S. (ed) (2016), «Enfance et famille autochtones », Enfance, Familles, Générations, n²5.

- Hudemann R. (2005), « Soldats français et femmes allemandes: les amours secrètes », in Tout a commencé par un baiser. Les relations germano-alliées après 1945 (2005), exhibition catalogue from the Musée des Alliés, October 2005-May 2006 (Berlin: Jaron Verlag) 28-37.

- Jablonka I. (2007), Enfants en exil. Transfert de pupilles réunionnais en métropole (19631982) (Paris: Le Seuil).

- Lexique de biopolitique. Les pouvoirs sur la vie (Toulouse, Érès, 2009), with: Ciccarelli R., «Citoyenneté »: 83-88; Marzocca O., « Biopolitique »: 43-50 ; Simone A., « Migrations »: 202-206.

- Mbembe A. (2006), «Qu'est-ce que la pensée postcoloniale ?», interview of, Esprit, (décembre 2006): 117-133.

- Pomfret D. M. (2016), Youth and Empire. Trans-colonial Childhoods in British and French Asia (Stanford University Press).

- Rolland, D. (2006). De sang mêlé. Chronique du métissage en Indochine (Toulouse: Elytis)

- Rosental P.-A. (2003), L'intelligence démographique. Sciences et politiques des populations en France (1930-1960) (Paris: Odile Jacob).

- Revue d'Histoire de l'Enfance "Irrégulière » on «Enfances déplacées », 1 - en situation coloniale, $\mathrm{n}^{\circ} 14$ (2012), 2 - en temps de guerre, $\mathrm{n}^{\circ} 15$ (2013).

- Sachs D. (2010), The Life We Were Given: Operation Babylift, International Adoption, and the Children of War in Vietnam (Beacon Press).

- Schaub J.-F. (2008), «La catégorie "études coloniales" est-elle indispensable? », Annales. Histoire, Sciences Sociales $63^{\mathrm{e}}$ année, n³: 625-646.

- Stoler A. L. (2002), Carnal Knowledge and Imperial Power: Race and the Intimate in Colonial Rule, (Berkeley: University of California Press).

- Soulé B. (2007), «Observation participante ou participation observante ? Usages et justifications de la notion de participation observante en sciences sociales » Recherches Qualitatives n²7: 127-140.

- Tara Zahra T. (2011), The Lost Children. Reconstructing Europes's Families after World War II (Cambridge and London: Harvard University Press) with "Children as Spoils of War in France" 146-172.

- Taraud C. (2008), «Les yaouleds: entre marginalisation sociale et sédition politique », Revue d'Histoire de l'Enfance "Irrégulière », n 10, 59-74.

- Virgili F. (2009), Naître ennemi. Les enfants de couples franco-allemands nés pendant la seconde guerre mondiale (Paris: Payot).

\footnotetext{
1 Ministère des Affaires étrangères (MAE) Archives of the direction des Personnes Déplacées et Réfugiées (PDR), $\mathrm{n}^{\circ}$ 63, compte rendu June 29, 1946 on meeting June 12, 1946 in Paris.

2 Haut-Commissariat de la République française en Allemagne, Service des Personnes Déplacées, Sept ans d'activité en faveur des personnes déplacées en zone française d'occupation, 1945-1952, rapport dactylographié et illustré, s.1.n.d., 166 p. ; MAE PDR n 272, recherches et reconnaissances de paternité 1946-1948; ${ }^{\circ} 330$, lettre de l'administrateur général au gouverneur délégué de l'Etat rhénan-palatin, February $1947 ; \mathrm{n}^{\circ} 285$, « Recensement des enfants dont l'un des parents est ressortissant des nations unies », s.d.

3 MAE PDR n 332, procès-verbaux d'abandons d'enfants.
} 
4 MAE PDR n 289, correspondance ; n²90, L’Amitié Chrétienne, « liste des enfants adoptés jusqu'au 31 mars $1948 » ; n^{\circ} 106$, lettre de la responsable des pouponnières en Allemagne (Nordrach) à la Fondation d'Heucqueville (Paris), October 6, 1947.

5 MAE PDR n ${ }^{\circ}$ 64, lettre du ministère des Affaires étrangères au Haut-Commissaire en Allemagne, October 4, 1950.

6 See Jacques Chancel, La nuit attendra (Paris: Flammarion, 2013).

7 Archives nationales d'outre-mer (ANOM), 90 APC n 4291 à 4295 : rapports annuels d'activités de la FOEFI ; Historique de la FOEFI présenté par William Bazé lors du Conseil d'administration de clôture de la FOEFI, le 7 novembre 1983. http://foefi.net/naissancedelafoefi.html.

8 Many personal accounts in two documentary films: Rostan, P. Inconnu présumé français, France, $2009,90 \mathrm{mn}$ et Pollet-Rouyer, F. Né sous Z. France-Belgique, 2010, $75 \mathrm{mn}$.

9 ANOM, $90 \mathrm{APC} \mathrm{n}^{\circ} 4291$, compte rendu de la situation à Rilly (1957) ; témoignage d'un ancien de Semblançay, Grain de riz n41 (June 2010) 4-5 and 8.

10 Archives of the abbey of Saint-Rambert; "Livre d'or William Bazé", Association Français Libres : http://www.francaislibres.net/liste/fiche.php?index=53982\&page=0

11 Interviews with Jeannette G., Paule M. et Nina V. January and February 2018.

12 Jacques Massu, La vraie bataille d'Alger (Paris: Plon, 1971) 191. Bab El Oued is the popular European neighbourhood in Algiers. It is located near the Casbah, popular Muslim neighbourhood and nationalist stronghold where the Battle of Algiers mostly occurred.

13 Suzanne Massu, Quand j'étais Rochambelle (Paris: Grasset, 1969), Un commandant pas comme les autres (Paris: Fayard, 1971).

14 Archives of Association pour la Formation de la Jeunesse (AFJ), assemblée générale constitutive, April 8, 1957.

15 France Inter, «Radioscopie » Suzanne Massu, 1971; interview with Rodolphe Massu, June 6, 2016, Billère (64).

16 «La Casbah des enfants perdus », Le Figaro, 15 juin 1959; INA, « Le nouveau chemin de la vie : les yaouleds », Cinq Colonnes à la Une, 8 mai 1959.

17 AFJ, Conseil d'administration, November 17, 1962, déclaration de Suzanne Massu.

18 Interview with Jacques L., general director of the organisation at the time, June 6, 2016, Arcachon (33) ; AFJ, rapport moral December 7, 1961 - Novembre 161962.

19 Interview with Moussa A.-C., December 19, 2016, Pau (64); Daniel Belafekir, Guerre d'Algérie. Le traumatisme de mon enfance (Nice: Éditions Bénévent, 2009) 47-48.

20 Jacques Massu, Le torrent et la digue (Paris : Plon, 1972) 117; «Entretien avec Jacques Massu », Le Monde, 23 juin 2000.

21 MAE PDR Sept ans d'activité en faveur des personnes déplacées... op. cit., pp. 95 et 97.

22 MAE PDR $\mathrm{n}^{\circ} 343$ et 344, lists of children accepted or refused for an adoption in France by Medical Commission (1946-1950).

23 MAE PDR $n^{\circ}$ 62, lettre du chef de la $2^{\mathrm{e}}$ section au directeur PDR, April 10, 1948.

24 MAE PDR, Sept ans d'activité en faveur des personnes déplacées... op. cit., p. 96 et 99.

25 MAE PDR n ${ }^{\circ}$ 62, note du HCA à l'attention de la direction PDR, July 18, 1950 ; several draft responses, particularly from 27 July and 31 August

26 Idem.

27 Account of M. Prugnaud, 2009. http://www.coeurssansfrontieres.com/fr/enfantdelaguerre/

28 Archives nationales, 19960015 n²2, conseil d'administration de la FOEFI, November 71983.

29 For a review of the concepts : Michel Wieviorka, «L'intégration : un concept en difficulté », Cahiers internationaux de sociologie n¹25 (2008/2) 221-240 ; Stéphane Beaud et Gérard Noiriel « L’"assimilation", un concept en panne », Revue internationale d'action communautaire $\mathrm{n}^{\circ} 21$ (1989) 63-76

30 Interview with Michel (Mokrane) F. April 19, 2016, Boufféré (85). Marc Désaphy, L'aventure algérienne dans l'ombre du général Massu (Paris: Éditéal, 2012), the author collaborated with Suzanne Massu and worked in the organisation for many years. Interview with Jacques L. 2016.

31 ANOM, 90 APC n²291, exercice FOEFI 1950.

32 How the boys shaped themselves as individuals and developed their senses of self is better documented because they expressed themselves more than the girls did, particularly in Grain de Riz, the FOEFI newsletter.

33 AFJ, Conseil d'administration November 25, 1962, rapport moral December 7, 1961 - November $16,1962$. At the time, AFJ had 136 children and teenagers, students or apprentices.

34 Interviews with Frédéric (Mohamed) F., 22 juillet 2015 et 6 juin 2016, Pau (64) et Michel (Mokrane) F. Interviews with responsibles : Jacques L. et Marc Désaphy, 2016.

35 Daniel Belafekir, Guerre d'Algérie... op. cit., 39-41.

36 Interviews with Moussa A.-C., Frédéric (Mohamed) F., Michel (Mokrane) F. et de Francis (Ahmed) R. July 22, 2015 and June 7, 2016, Pau (64).

37 AFJ, Conseil d'administration June 9, 1966. 
38 AFJ, Conseil d'administration October 28, 1965.

39 In 2014, the French National Assembly recognised the state's "moral responsibility" in negligence related to these displacements and their consequences. In February 2018, measures to aid victims were announced.

40 «Association FOEFI » created in 1987 by former residents of FOEFI care homes. It publishes a newsletter: Grain de Riz, http://foefi.net/

41 Accounts in Grain de riz, n41 (June 2010) 5. The life of a Eurasian who stayed in Vietnam: Pham Ngoc Lân, De père inconnu. Récits dut le Viêt Nam de la deuxième moitié du XX $X^{e}$ siècle (Paris: L'Harmattan, 2015).

42 Interview with Michel F., 2016 ; Interviews with Monique P., Yvonne F. and Marie-Simone L., February and March 2018. 